\title{
Examining the Impact of Antecedents of Firm Performance on Companies in South Africa
}

\author{
Elizabeth Chinomona* \\ Department of Logistics, Vaal University of Technology, Vanderbijlpark, South Africa \\ chakubvaelizabeth@gmail.com
}

\begin{abstract}
The aim of this study is to establish the impact of social media, information sharing and knowledge sharing on firm performance among companies in South Africa, Gauteng province in particular. In as much as the issue of social media communication has received great benefits and growth within organisations, little has been researched about the impact of social media on job performance, knowledge sharing and information sharing among companies in the Gauteng province, South Africa. Social Identity Theory (SIT) has been used to explain the associations in the model. Questionnaires were distributed to both management staff and lower level employees in the companies in Gauteng province of South Africa. This study used a quantitative research methodology using Smart PLS software. This software was employed to test the relationships among the four hypotheses. The results showed that there is a positive and significant relationship among the four proposed hypotheses. Basing on the findings of this research, recommendations were made to both the top-level employees and lower level employees in the companies in South Africa. This study is expected to have real-world and academic implications to policymakers for the companies in South Africa. On top of this, the study will provide new insights and added first-hand knowledge to the existing body of literature which is meagre in South African companies.
\end{abstract}

Keywords: Social media, Knowledge sharing, Information sharing, Firm performance, Social Identity Theory

\section{Introduction}

The importance of this study is to establish the impact of social media, information sharing and knowledge sharing on firm performance of companies in the Gauteng province of South Africa. There are four empirical goals of this study which are to investigate the relationship between social media and knowledge sharing, examining the association between social media and information sharing, to scrutinize the relationship between knowledge sharing and firm performance and lastly to establish the relationship between information sharing and firm performance. The significance of the study is to investigate the influence of the predictor which is social media on mediators which is knowledge sharing and information sharing and the outcome variable which is firm performance. Efficacy in communication has been an essential element in the success and smooth running of any organization (Gupta, Seetharaman \& Raj 2013; Felix, Saboo, Kumar, \& Ramani 2016; Rauschnabel \& Hinsch 2017). Pooe, Mafini and Loury-Okumba (2015) argued that communication is a basic prerequisite for the attainment of organisational goals and objectives in terms of customer relationship and organisation's relationship. The survival of any organisation depends on its operational communication competence (Sidorova, Amaboldi \& Radaelli 2016).

Through communication, an organisation can achieve high level of performance, outperform competitors, improve brand reputation, and enhance both customer trust and employee trust, meet customers' requirements and expectations as a promise (Dong \&Wu 2015; Brooks \& Califf 2016; Sidorova, Amaboldi \& Radaelli 2016; Saboo, Kumar \& Ramani 2016). In the present business environment communication through socials media is vital and establish solid organisation's relationship with suppliers, which has resulted into win-win advantages (Vasquez \& Velez 2011; Macnamara \& Zerfass 2012; Baruah 2012; Neves \& Errami 2016). Open communication is one of the key strategies for organizations' knowledge, information sharing and performance such exchanges is important for the growth and performance of organisations. Many organisations today, still find it difficult to understand and explore information and knowledge sharing to enhance performance through social media platforms (Chumg, Seaton, Cooke \& Ding 2016). Since social media is seen as the future of communication and as an effective means for knowledge sharing and information sharing within organizations (Badea 2014), this study therefore set out to investigate the influence of social media impact on knowledge sharing and information sharing for the enhancement of firm performance. 


\section{Literature Review}

Social Identity Theory: Social identity theory (SIT) has been used in this study to elucidate the relationships among social media, information sharing knowledge sharing and organisational performance. This is because social identification results to devotion, belongingness, support for the organisation and ultimately good firm performance. SIT leads to outcomes that are traditionally associated with group formation and reinforces the antecedents of identification. Organisational identification has long been recognised as a critical construct in the literature of organisational behaviour affecting both the satisfaction of the individual and the effectiveness of the organization (Ashforth \& Mael 1989). In this regard, social identities are often developed through social interactions (Li, Xin \& Pittutla 2002) and, therefore, can be used to explain firm performance in organisations. The extant literature indicates that the SIT is drawn from intergroup theory, which was developed by social psychologists to describe the effect of group membership on intergroup behaviour where employees share knowledge and general information (Carmon, Miller, Raile \& Roers 2010). As for SIT, people tend to classify themselves and others into various social categories.

These categories include organisational membership, religious affiliation gender and age cohort. Ashforth and Mael (1989:20) defined social identification as a perception of oneness with a group of persons. This stems from the categorisation of individuals, the distinctiveness and prestige of the group, the salience of outgroups and the factors associated with group formation. Ashforth and Mael (1989) showed that identification with the group leads to activities that are congruent with the distinctiveness, provision for institutions that embody the identity, stereotypical perceptions of self and others and outcomes that are traditionally associated with group formation. According to the SIT, an individual does not have a single personal identity, but multiple social identities (Tajfel \& Turner 1979:33; Terry, Hogg \& White 1999:225; Hogg \& Vaughn 2002:6). One's social identity is formed as an individual place oneself into distinct social categories based on similarities with these groups, such as students, Christians, or females (Scott 2007). It is also through this process that individuals develop their organisational identities, a specific type of social identity through associating themselves with others in their organisations and reflecting on these comparisons over time. Relating the SIT to the current research context, this study submits that, for instance, employees in South African companies can develop organisational identities to their current organisation based upon their judgement of their company and other companies (Carmon et al., 2010).

This implies that when employees find their group identity with a company it is very important to them an attempt is made to distinguish themselves from other companies (Abrahams, Hogg, Hinkle, \& Otten 2005). Thus, a group of employees belonging to one company may feel more attached to their company hence their overall organisational identity (Hogg, Abrahams, Otten \& Hinkle 2004). It is, therefore, submitted in this study that the more favourable the comparisons of an organisation an employee perceives of his or her company or the more distinct it is from other companies, the stronger the expected foundation of a positive social identity. It is anticipated also that stronger organisational identity in companies is forged when individual employees perceive their values to match that of the organisation. In this case, workplace interactions and organisational value congruence foster organisational identity in the company's context (Pratt 1998). Nevertheless, when an employee does not identify with an organisation, it can lead to distrusting organisational information or to interpretation of information in a way that reinforces feelings of disidentification (Dukerich, Kramer \& Parks 1998). Cheney (1883: 8) concluded that "organisational identification seems to be a specific type of social identification that elicits perceptions of shared values, belonging and loyalty to an organization".

Burke (1937:140) maintains that individuals naturally respond to divisions by identifying with other individuals or groups and identification essentially becomes "the function of sociality...one's participation in a collective, social role cannot be obtained in any other way". Identification, therefore, is important for employees who must navigate inevitable divides in order to find their fit within companies. By developing an overall organisational identity, people are able to develop a strong sense of cohesion among family member employees and perhaps encourage other employees to buy into their vision and values (Zellweger, Eddleston \& Kellermanns 2010). Social identification not only encourages participation in organisational decision making, but also encourages the development of a strong sense of identification with companies (Zellweger et al., 2010). If companies succeed in creating a sense of belonging and identification for member employees, the perception that employees have been let into the company may be enough to create a sense of commitment 
and ultimately high firm performance. As organisational identification increases, it positively influences a variety of work attitudes, behaviours and outcomes.

Organizational identification is linked theoretically and empirically to motivation, decision making, employee interaction and length of service (Cheney, 1983:342); turnover and turnover intentions (Mael \& Ashforth 1992; Van Dick, Christ, Stellmacher, Wagner, Ahlswede \& Grubba 2004) and job satisfaction and performance (Carmeli, Gilat \& Waldman 2007). Organisational identification plays an important role in employees' wellbeing, satisfaction and productivity and has promising potential for increasing firm performance (Scott et al., 2007; Van Dick et al., 2004). Becker (1992:233) noted that the primary motives for commitment to an organisation are identifying with the organisation. Individuals who embrace their organisation's goals and missions through identification processes are more likely to remain committed to their organisations than individuals who do not (Van Dick et al., 2004). Ellemers, Spears, and Doosje (1997:618) found that individuals who had stronger in-group identification were more likely to display a commitment to their workgroups. Consequently, if an employee begins to identify with an organisation, particularly if they perceive they are a member of the in-group then it is likely they will also begin to feel more committed to the organisation and stay within the organization and increase the productivity and firm performance.

Social Media: The growing acceptance of social media in this modern time did not only change the social life of individual and regular internet users alike, but also to a great extent has enhanced organisation growth and productivity both within and outside the organization (Swani, Milne, Brown, Assaf \& Donthu 2016; Wu 2016; Wang, Pauleen \& Zhang 2016). The development of social media has become the greatest events in recent years for organizational learning (Moghavvemi, Sharabati, Paramanathan \& Rahin 2017). This is because social media represents a new strategy for organisations to gain a competitive advantage and enhance job performance in contemporary society (Nascimento, da Silveira 2016). Social media is an aided computerbased technology or an internet-based application in which members of organisations are able to create knowledge, share relevant information and contents as well as participate in social networking activities (Rauniar, Rawski, Yang \& Johnson 2014). Wu, Li and Chang (2016:870) defined social media as "the interactive platforms generated by mobile and web-based technologies on which individuals and communities can share, co-create, discuss and modify user-generated content". Social media is a countless array of internet-based tools and platforms that increase and enhance the knowledge sharing and sharing of information. For example, Facebook, Skype, Wikipedia, Google +, LinkedIn, YouTube and Twitter are social network platforms that allow organisations own their website page and applications for quick and easy transfer of text, photos, audio, video, knowledge and information sharing (Rauniar, Rawski, Yang \& Johnson 2014; Quinton \& Wilson 2016; Pinho-costa, Yakubu, Hoedebecke, Laranjo, Reichel, Colon-Gonzalez, Neves \& Errami 2016).

Information and Knowledge Sharing: Information sharing is denoted to as the exchange of data between people, organisations and social media as well as communication technology. Social media and the developing internet platforms have contributed immensely to the growth of information sharing globally. During the earlier days, the physical transfer of information or data to and among other entities was a nightmare due to its non-portable format and also the inability to import and export data. But today, information sharing has been made possible and common through social media platforms. Social media encourages information sharing capability. Organisations need information sharing capabilities in order to respond to market needs effectively and to enhance performance. "Using information sharing platforms intelligently has been shown to be a more effective way to manage any organization" (Quinton \& Wilson 2016:16). The efficiency of the organisation can be enhanced through information. Information sharing is important to organisations as it is prerequisite to customer relationship building. Valuable information sharing is a useful way of lowering costs, improving the overall accuracy of product and services data and also as a way of gaining access to relevant information. Information sharing is a prerequisite to knowledge sharing. Knowledge sharing is an essential part of knowledge management and as such, it is more than just sharing information or exchanging data.

Knowledge sharing is the exchange of skills, vision experience and expertise among organisations so that new information can be created, evaluated understood and interpreted for organisational improvement and development (Navimipour \& Charband 2016). However, for knowledge sharing to take place it requires that individuals or organisations involved are willing to share their knowledge in order to receive knowledge 
(Moghavvemi et al., 2017). Li, Zhang, Zhang and Zhou (2016), made it clear that "knowledge sharing is a process in which individuals exchange their knowledge and create new knowledge together. It comprises two categories of behavior: knowledge donating, which refers to passing on one's own intellectual capital to others and knowledge collecting, which refers to consulting others in order to acquire some of their intellectual capital". Therefore, knowledge sharing requires some level of commitment, trust, willingness and collaboration among parties involved in learning and improvement (Tseng \& Huang 2011). Knowledge is the understanding of facts, information and description, as well as the acquisition of skills through experience and education. Knowledge sharing seeks to make information meaningful, accessible, and usable among organisations in order to create and gain competitive advantage (Paulin \& Suneson 2012).

Social Media Influence on Knowledge Sharing and Information Sharing: Ryden, Ringberg and Wilke (2015), Rauniar et al. (2014) noted that social media is rapidly changing and transforming the way organisations communicate with their customers and with each other. Social media aid the simplification of information sharing and knowledge sharing (Quinton \& Wilson 2016; Chung, Andreev, Benyoucef, Duane, \& O'Reilly 2016). For example, in late 1960, organisational cross-functional meetings could not hold except there be a face-face interface with the respective individuals. However, in this $21^{\text {st }}$ century, the reverse is the case, where organisations can now schedule their meeting through Skype without having to meet face to face as opposed to late 1960 (Wu et al., 2016). Nisaf and Wickramasinghe (2013) prove that social media, information sharing is easy and cost-effective, create opportunities for business collaboration and knowledge sharing is accurate, convenient with effective feedback. Organisations now advertise and promote their product brands, image and reputation through social media (Chung, Andreev, Benyoucef, Duane, \& O'Reilly 2016). Swani et al. (2016:2) argued that social media communication "enables marketing organisations to influence brand outcomes and purchase decisions through fan promotion and popularization of brand content". It is widely known that external collaborative relationships between organisations are essential to enhancing productivity and as such, social media is believed to be important (Nascimento, da Silveira 2016). The collaborative relationship between organisations necessitates unceasing information flow, trust, engagement and commitment of which social media play an essential role (Wang, Pauleen \& Zhang 2016).

Social media help organisations improve on their collaborative strength through flexible participation and quick response which in turn may result into leaning, information sharing, gaining new knowledge and increased productivity ( $\mathrm{Wu}$ et al., 2016). An effective tactic that allows organisations to easily and conveniently interact with customers', influence sales, enhance responsiveness, build relationships, increase brand awareness, customers' loyalty and enhancement of information sharing and knowledge sharing is the essence of social media communication popularity among organizations (Gupta, Seetharaman \& Raj 2013; Quinton \& Wilson 2016; Wang et al., 2016). According to Moghavvemi et al. (2017), information sharing provides solutions, new insights and mechanisms for knowledge sharing among organizations. Social media is also progressively rising in popularity among employees and office workers alike for information and knowledge sharing (Tseng \& Huang 2011; Razak, Pangil, Md Zin, Azlina, Yunus \& Asnawi 2016; Ou, Davision, \& Wong 2016). Knowledge and information sharing among employees influence positively organisation's sustained competitive advantages and business objectives (Sivertzen, Nilsen \& Olafsen 2013). As a result, organisations and academic institution now seek to empower and motivate their employees towards the use of social media technology platform to communicate with customer and shareholder in order to be more effective on firm performance and productivity (Hansen \& Levin 2016; Ismaeel \& Qammach 2016; Kwahk \& Park 2016). Therefore, social media is an essential source of information sharing and knowledge sharing.

H1: There is a significant and positive impact between social media and knowledge sharing H2: Social media has a significant and positive impact on information sharing

Knowledge Sharing Influence on Firm Performance: Knowledge sharing has been used interchangeably with information sharing. Knowledge sharing is considered more valuable resources because knowledge sharing enhances organisation's capability to manage effectively information and resources, as well as to enable significant return on investment (Tseng \& Huang 2011; Kuzu \& Ozilhan 2014; Chumg, Seaton, Cooke \& Ding 2016). One of the reasons for organisation's decision to be in a collaborative relationship with other organisations is to enable it to get access to relevant information and knowledge on emerging trends driving market needs and demands that would have been impossible working in isolation (Trivellas, Akrivouli, 
Tsifora \& Tsoutsa 2015; Olaisen \& Revang 2017). With the shared information, knowledge on how to strategically manage inventory forecast and implement necessary strategy may emerge (Akturan \& Gunduz Cekmecelioglu 2016). A mutual relationship among organisations can generate relevant and competitive information on market ideas, thereby enhancing and improving organisational performance as well as a sustained competitive advantage (Razak, Pangil, Zin, Yunus \& Asnawi 2016; Wang, Sharma \& Cao 2016; Llopis \& Foss 2016). Knowledge sharing provides important information and know-how to solve problems and develop new ideas (Ismaeel \& Qammach 2016; Hussain, Konar \& Ali 2016). According to Li, Zhang, Zhang and Zhou (2016), effective knowledge management enables an organisation gain a competitive advantage over rivals due to its positive influence on "cost reduction, new product development, team performance, innovation and organisational performance". Therefore, the following hypothesis is postulated:

H3: Knowledge sharing has a significant and positive relationship with firm performance

Information Sharing Influence on Firm Performance: Scholars have recognised information sharing as the vital spark of logistics and supply chain integration; market relationship with key customers and suppliers as well as materials flow (Wu, Chuang \& Hsu 2014; Pooe, Mafini, \& Loury-Okoumba 2015; Tong \& Crosno 2016; Bian, Shang \& Zhang 2016). The lack of information sharing in an organisation may result to a poor performance level as the organisation may not be able to cope with the market pressure and demands (Srikanth \& Jomon 2013; Munirat, Sanni \& Kazeem 2014). Information sharing enables organisations to satisfy its customers' specific needs and requirements (Hatala \& Lutta 2009). It enables the efficiency and effectiveness of the organisation resources. This is due to its potential to keep organisations up-to-date and ensuring business competitive performance as well as long-term collaborative relationship improvement with external organizations (Bontis, Richards \& Serenko 2011). Information sharing enhance the visibility of products and services supplied (Gil-Garcia \& Sayogo 2016). According to Lotfi, Mukhtar, Saharan and Zadeh (2013:298), "in order to survive and compete effectively in today's global economy, organisations strongly need to create, share and disseminate up-to-date and appropriate knowledge and information". The hypothesis is stated as follows:

H4: There is a significant and positive impact between information sharing and firm performance

\section{Figure: 1}

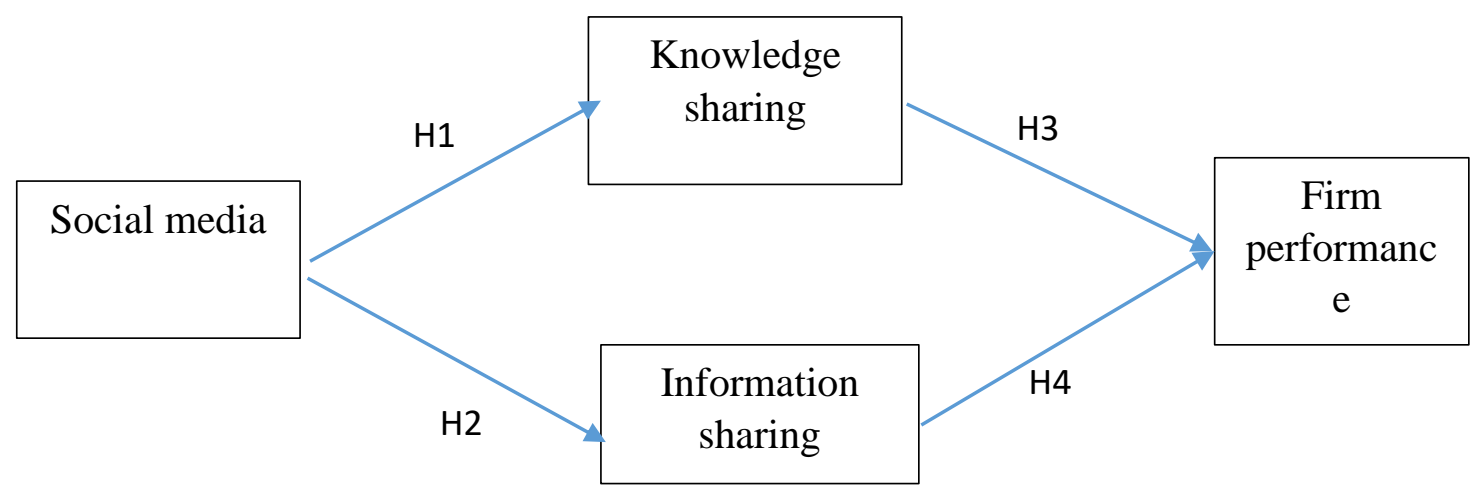

\section{Research Procedure}

A quantitative cross-sectional survey strategy was used to scrutinize the impact of social media on knowledge sharing, information sharing and firm performance among companies in the Gauteng province of South Africa.

Measurement Items: Previous work was used to design the questionnaires. Some slight modifications were made in order to fit the current research context and purpose. Social Media was measured using five-item scales adapted from Hansen and Levin (2016). One item which is SM 4 was deleted because the factor loading was below the recommended value of 0.5 . Knowledge sharing used a five-item scale measure adapted from Moshabbaki and Jaha'nyan (2009). Information Sharing used a five-item scale measure adapted from $\mathrm{Wu}$, 
Chuang and Hsu (2014). Firm performance was measured using a six-item scale, from Tseng and Huang (2011). FP 3 was deleted due to the factor that the value did not meet the recommended threshold. A fivepoint Likert-type scale was used to measure the validity and reliability of the instruments.

Sample Description: 233 questionnaires were distributed to both management and lower level employees in the companies in the Gauteng province of South Africa because they are the ones with immense knowledge the running of the company. A sample size of 100 to 300 respondents is good for reliability and validity reasons when running Smart PLS (Nunnally \& Bernstein 1994). Therefore, 233 questionnaires used in this study within the recommended range. They also have information concerning social media, knowledge sharing information sharing and firm performance. This requires people with internal information that's why this target population was chosen. Two hundred and twenty-two questionnaires were returned of which only 185 were usable. This yielded a valid response rate of 79\%. Descriptive statistics in Table 1 show the gender, age and marital status of employees in the companies.

Table 1: Descriptive Statistics

\begin{tabular}{lll}
\hline Gender & Frequency & Percentage \\
\hline Male & 97 & $52 \%$ \\
Female & 88 & $48 \%$ \\
Total & $\mathbf{1 8 5}$ & $\mathbf{1 0 0 \%}$ \\
& & \\
Age & Frequency & Percentage \\
$\leqq 30$ & 60 & $32 \%$ \\
$31-60$ & 109 & $59 \%$ \\
$\geqq 60$ & 16 & $9 \%$ \\
Total & $\mathbf{1 8 5}$ & $\mathbf{1 0 0 \%}$ \\
Marital status & Frequency & Percentage \\
Married & 52 & $28 \%$ \\
Single & 133 & $72 \%$ \\
Total & $\mathbf{1 8 5}$ & $\mathbf{1 0 0 \%}$ \\
\hline
\end{tabular}

More males took part in the study as shown in Table 1 . They constituted $52 \%$ of the total respondents. On the other hand, females made up $48 \%$ of the total respondents. In terms of the age groups of respondents, individuals who were less than 30 years of age were 60 in total which is equivalent to $32 \%$ in the study. Those aged between 31 and 60 participated more in the study and they represented $59 \%$ of the total population. The least group were those above 60 years of age which constituted about $9 \%$ only. Married participants constituted $28 \%$ of the sample while those who were single constituted $72 \%$ of the total participants.

Psychometric Assets of the Measurement Scale: Table 2 reports the validity and reliability of the measurement scale. The table shows the Research constructs, Cronbach alpha test, Composite reliability (CR), Average variance extracted (AVE) and item loadings.

Table 2: Accuracy Assessment and Descriptive Statistics

\begin{tabular}{|c|c|c|c|c|c|c|c|}
\hline \multirow[t]{2}{*}{ Research Constructs } & \multicolumn{2}{|c|}{$\begin{array}{l}\text { Descriptive } \\
\text { statistics* }\end{array}$} & \multicolumn{2}{|c|}{$\begin{array}{l}\text { Cronbach's } \\
\text { Alpha test }\end{array}$} & \multirow[t]{2}{*}{ C.R. } & \multirow[t]{2}{*}{ AVE } & \multirow[t]{2}{*}{$\begin{array}{l}\text { Item } \\
\text { Loading }\end{array}$} \\
\hline & Mean & SD & $\begin{array}{l}\text { Item- } \\
\text { total }\end{array}$ & $\begin{array}{l}\alpha \\
\text { Value }\end{array}$ & & & \\
\hline \multicolumn{8}{|l|}{ Social Media (SM) } \\
\hline SM 1 & & & 0.453 & & & & 0.460 \\
\hline SM 2 & & & 0.602 & & & & 0.671 \\
\hline SM 3 & 2.09 & 1.711 & 0.806 & 0.712 & 0.710 & 0.550 & 0.861 \\
\hline SM 4 & & & 0.704 & & & & 0.789 \\
\hline \multicolumn{8}{|l|}{ Knowledge Sharing (KS) } \\
\hline KS 1 & & & 0.510 & & & & 0.612 \\
\hline
\end{tabular}




\begin{tabular}{|c|c|c|c|c|c|c|c|}
\hline \multicolumn{8}{|c|}{$\begin{array}{c}\text { Journal of Economics and Behavioral Studies (ISSN: 2220-6140) } \\
\text { Vol. 10, No. 6A, pp. 30-42, } 2018 \\
\end{array}$} \\
\hline KS 2 & & & 0.492 & & & & 0.583 \\
\hline KS 3 & 3.11 & 1.106 & 0.787 & 0.820 & 0.820 & 0.699 & 0.830 \\
\hline KS 4 & & & 0.798 & & & & 0.860 \\
\hline KS 5 & & & 0.803 & & & & 0.870 \\
\hline \multicolumn{8}{|c|}{ Information Sharing (IS) } \\
\hline IS 1 & & & 0.789 & & & & 0.842 \\
\hline IS 2 & & & 0.742 & & & & 0.822 \\
\hline IS 3 & 3.55 & 1.398 & 0.733 & 0.858 & 0.859 & 0.705 & 0.805 \\
\hline IS 4 & & & 0.722 & & & & 0.813 \\
\hline IS 5 & & & 0.646 & & & & 0.729 \\
\hline \multicolumn{8}{|c|}{ Firm Performance (FP) } \\
\hline FP 1 & & & 0.639 & & & & 0.738 \\
\hline FP 2 & & & 0.641 & & & & 0.753 \\
\hline FP 4 & 2.30 & 1.704 & 0.508 & 0.800 & 0.800 & 0.578 & 0.545 \\
\hline FP 6 & & & 0.687 & & & & 0.735 \\
\hline \multirow{2}{*}{\multicolumn{7}{|c|}{$\begin{array}{lc}\text { FP } 6 & 0.704 \\
S M=\text { Social Media } \cdot K S=\text { Knowledae Sharina } \cdot I S=I n \text { formation Sharina } \cdot F P=\text { Firm Performance }\end{array}$}} & 0.776 \\
\hline & & & & & & & \\
\hline
\end{tabular}

SM 1 has the lowest figure of 0.453. If this figure is rounded off to the nearest whole number, it becomes 0.500 which is within the recommended threshold whilst the highest was SM 3 with 0.806 . The lowest factor loading observed was SM 1 with 0.460 which is less than the acceptable value of 0.5 but if this figure is rounded off to the nearest whole number it becomes acceptable which is 0.500 and the maximum was KS 5 with 0.870 . This shows that the measurement instruments are valid. On the other hand, the lowest Cronbach alpha was 0.712 and the highest was 0.858 which shows that the constructs were internally consistent or reliable and explained more than $70 \%$ of the variance. In addition, all composite reliability values were above the recommended minimum of 0.7 (Bagozzi \& Yi, 1988), which further attests to the reliability of the measurement instrument used in the study. One of the methods used to ascertain the discriminant validity of the research constructs was the evaluation of whether the correlations among latent constructs were less than 0.60 . These results are reported in Table 3.

Table 3: Inter-Construct Correlation Matrix

\begin{tabular}{lllll}
\hline Variables & FP & IS & KS & SM \\
\hline FP & $\mathbf{0 . 5 4 9}$ & & & \\
IS & 0.410 & $\mathbf{0 . 5 0 0}$ & & \\
KS & 0.300 & 0.333 & $\mathbf{0 . 4 5 1}$ & $\mathbf{0 . 5 0 4}$ \\
SM & 0.450 & 0.481 & 0.442 & \\
\hline
\end{tabular}

SM=Social Media; KS= Knowledge Sharing; IS=Information Sharing; FP= Firm Performance

0.60 or less is endorsed in the empirical literature to confirm the existence of discriminant validity (Bagozzi \& Yi, 1988). As can be observed from Table 3, all the correlations were below the acceptable level of 0.60 . The diagonal values in bold are the Shared Variances (SV) for the respective research constructs. The Shared Variance is expected to be greater than the correlation coefficients of the corresponding research constructs. Drawing from Table 2 and 3 above, "the results further confirm the existence of discriminant validity. To ascertain convergent validity, the factor loadings were considered in order to assess if they were above the recommended minimum value of 0.5 " (Nunnally \& Bernstein, 1994:15). "The factor loadings for scale items (Table 2) were above the recommended 0.5 , which indicated that the instruments were valid and converging well on the constructs that they were expected to measure" (Anderson \& Gerbing 1988:33).

Path Modeling Outcomes: After checking the reliability and validity of the measurement instruments (reported in Table 2), the study continued to test the proposed hypotheses. In total there are three hypotheses that are tested. In the path model, Social Media (SM); Knowledge Sharing (KS); and Information Sharing (IS) are the predictor variables and Firm Performance (FP) is the outcome/dependent variable. Figure 2 provides the proposed hypotheses and the respective path coefficients. The same results of the path 
coefficients are tabulated in Table 2 depicting the Item to Total Correlations, Average Variance Extracted (AVE), Composite Reliability (CR) and Factor Loadings.

Path Model Outcomes and Factor Loadings: Below is Figure 2, indicating the path modelling results and as well as the item loadings for the research constructs. In the figure, SM stands for Social Media; KS is the acronym for Knowledge Sharing; IS stand for Information sharing; FP is the abbreviation for Firm Performance.

Figure 2: Path Modeling and Factor Loading Outcomes

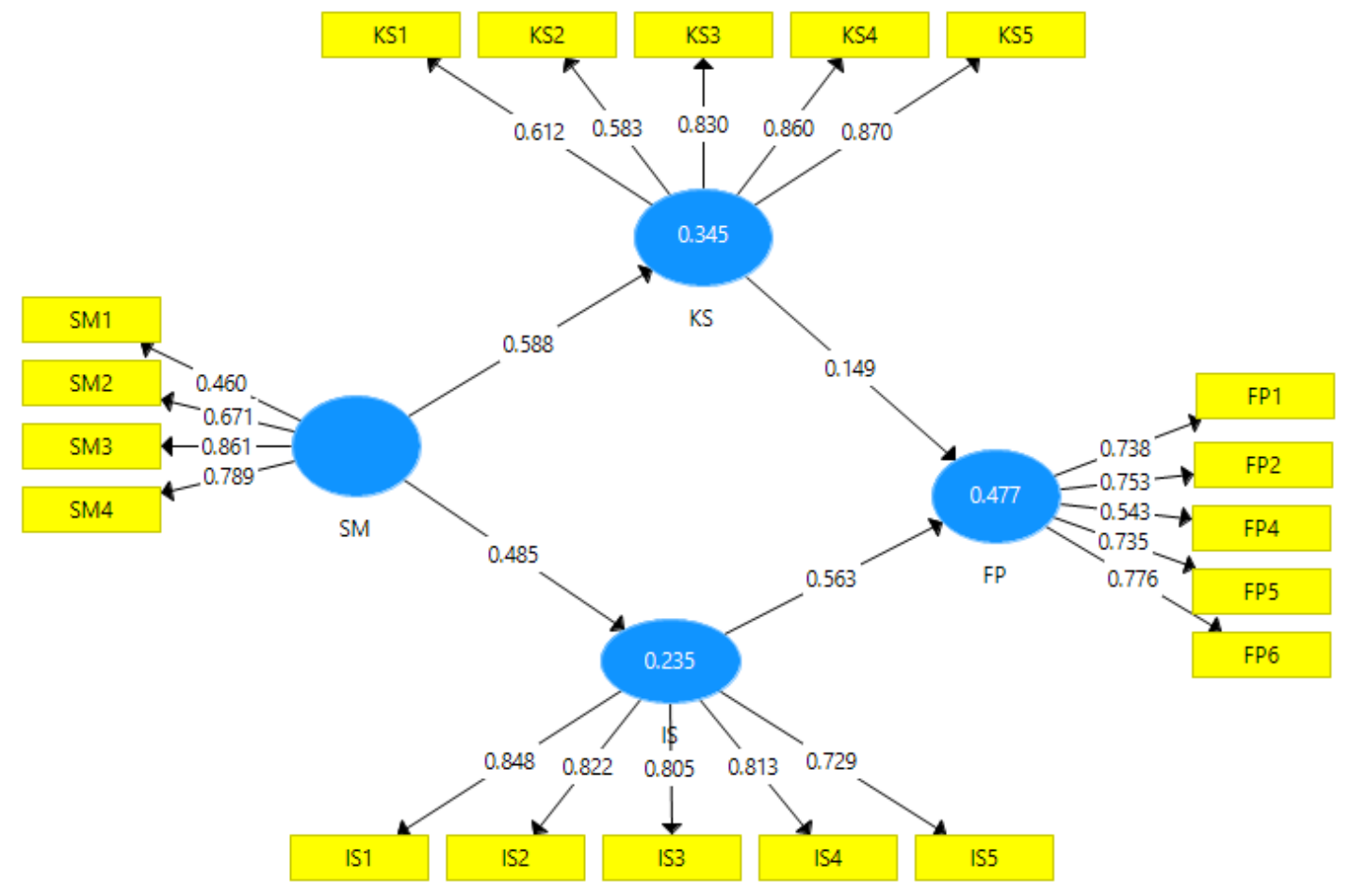

Table 4: Results of Structural Equation Model Analysis

\begin{tabular}{|c|c|c|c|c|}
\hline Path & Hypothesis & Path coefficients & T- Statistics & $\begin{array}{l}\text { Decision on } \\
\text { Hypotheses }\end{array}$ \\
\hline $\begin{array}{llll}\text { Social Media } & (\mathrm{SM}) & \rightarrow & \text { Knowledge } \\
\text { Sharing (KS) } & & & \end{array}$ & H1 & $0.588^{\mathrm{a}}$ & 8.499 & $\begin{array}{l}\text { Accept/ } \\
\text { Significant }\end{array}$ \\
\hline $\begin{array}{l}\text { Social Media (SM) } \rightarrow \text { Information } \\
\text { Sharing (IS) }\end{array}$ & $\mathrm{H} 2$ & $0.485^{a}$ & 7.333 & $\begin{array}{l}\text { Accept/ } \\
\text { Significant }\end{array}$ \\
\hline $\begin{array}{l}\text { Knowledge Sharing (KS) } \rightarrow \text { Firm } \\
\text { Performance (FP) }\end{array}$ & H3 & $0.149^{a}$ & 3.148 & $\begin{array}{l}\text { Accept/ } \\
\text { Significant }\end{array}$ \\
\hline $\begin{array}{l}\text { Information Sharing } \quad \text { (IS) } \rightarrow \quad \text { Firm } \\
\text { Performance (FP) }\end{array}$ & H4 & $0.563 a$ & 8.231 & $\begin{array}{l}\text { Accept/ } \\
\text { Significant }\end{array}$ \\
\hline
\end{tabular}

${ }^{a}$ Significance Level $\mathrm{p}<.10$; bignificance Level $\mathrm{p}<.05$; 'Significance Level $\mathrm{p}<.01$

As can be deduced from Table 4 above it shows the 4 hypothesised relationships, path coefficients, the tstatistics and the decision criteria. The value of the t-statistic indicates whether the relationship is significant 
or not. A substantial association is expected to have a t-statistics that is above 2. Drawing from the results provided in Table 4, four of the hypothesized relationships (H1, H2, H3, \& H4) were statistically noteworthy.

\section{Discussion of the Results}

The main objective of this study was to examine the influence of social media, knowledge sharing, and information sharing on firm performance in companies in the Gauteng province of South Africa. In this study, hypothesis one was supported. It can be observed in Figure 2 and Table 4 that social media exerted a positive influence $(r=0.588)$ and were statistically significant $(\mathrm{t}=8.499)$ in predicting knowledge sharing. This result implies that social media directly influence knowledge sharing in a positive and significant fashion the higher the level of social media, the higher the level of knowledge sharing. These results are in agreement with the study done by Ismaeel and Qammach (2016). The second hypothesis proposed that social media has a positive influence on information sharing. This hypothesis was reinforced in this study. Figure 2 and Table 4 indicate that social media and information sharing which is $\mathrm{H} 2$ was reinforced. Social media exerted a positive influence ( $r=0.485)$ on information sharing and were statistically substantial $(t=7.333)$. This result signifies that social media is positively and meaningfully related to information sharing. The results for this study concurred with the results found by Kuzu and Ozilham (2014) in their study.

On top of this, the third hypothesis, which advanced that knowledge sharing exerts a positive influence on firm performance was buttressed and acknowledged in this study. It is reported in Figure 2 and Table 4 that H3 knowledge sharing exerts a positive $(r=0.149)$ influence on firm performance, this impact is statistically significant $(\mathrm{t}=3.148)$. This outcome advocates that knowledge sharing has a direct positive effect on firm performance. Therefore, the more effective the knowledge sharing, the greater the positive firm performance Baruah, (2012) also concluded that knowledge sharing has a positive effect on firm performance. Moreover, the fourth hypothesis proposed that information sharing has a positive influence on firm performance. This hypothesis was reinforced in this study. Figure 2 and Table 4 indicate that information sharing and firm performance which is $\mathrm{H} 4$ was significant. Information sharing exerted a positive influence ( $r=0.563)$ on firm performance and was statistically substantial ( $\mathrm{t}=8.231)$. This result signifies that information sharing is positively and meaningfully related to firm performance. Thus higher levels of information sharing will lead to higher levels of firm performance. Information sharing leads to production boosting (Gil-Garcia \& Sayogo 2016).

Limitations and Future Research Directions: Weaknesses were observed during this research. First, the study was constrained to four constructs only forthcoming research could also include other constructs like trust and communication which can boost firm performance. In addition, the results are based on a small sample of 185 respondents, which makes it problematic to make a sweeping statement on the results to other contexts of investment companies in South Africa. Prospect studies could make use of bigger sample sizes in order to get views that are more representative. Despite the use of a quantitative approach, imminent studies could also use a mixed method approach so that in-depth views of higher education students can also be captured.

\section{Conclusion and Managerial Implications}

Factors such as social media, information sharing and knowledge sharing are instrumental in high firm performance. The study further confirms that firm performance is at its peak when the social media, knowledge sharing and information sharing support are highly valued by top management and low-level employees too. Social media ( $r=0.588)$ came out as the highest value amongst the 4 hypotheses. Social media has great influence on knowledge sharing and so companies should attempt by all means to increase the use of social media on firm performance in the companies in South Africa. To increase knowledge sharing spiritde-corps should be highly practised, teamwork and transparency at workplaces. Information sharing $(r=0.563)$ developed as the second highest scoring construct amongst the three factors impelling firm performance. Perhaps, this result could be attributed to the fact that most companies perform better if information sharing is free, correct and valid. Thus, in order to enhance good firm performance greater emphasis should be placed on good information sharing which should be very efficient and effective at whatever cost. The study has both theoretical and managerial implications. Theoretically, it makes a 
noteworthy progression in marketing theory by methodically examining the interplay between social media, knowledge sharing, information sharing and firm performance. However, the study is an important contributor to the existing literature on this subject.

The research model is also very robust and future researchers might try to use the same kind of model in a different context. The Social Identity theory enhanced immense knowledge on the relationships and links between the variables. Practically, social media, knowledge sharing and information sharing are instrumental in exerting a positive influence on firm performance and perfections in each of these three factors could arouse increased firm performance in South African companies. Social media can be improved through advertisements and good audience targeting. Knowledge sharing can be enhanced by self-development and transparency at workplaces. On the other hand, information sharing can be enriched through eradicating barriers in communication. Nevertheless, firm performance can be value-added by other means such as induction programmes, avoiding organisational politics and good business management practices.

\section{References}

Abrams, D., Hogg, M. A., Hinkle, S. \& Otten, S. (2005). The social identity perspective on small groups. In Poole M. S. \& Hollingshead A. B., eds. Theories of small groups: interdisciplinary perspectives. Thousand Oaks, CA: SAGE, 99-137.

Akturan, A. \& Gunduz Cekmecelioglu, H. (2016). The effect of knowledge sharing and organizational citizenship behaviours on creative behaviours in Educational Institutions. Procedia-Social \& Behavioral Sciences, 235, 342-350.

Anderson, J. C. \& Gerbing, D. W. (1988). Structural equation modelling in practice: a review and recommended two-step approach, Psychological Bulletin, 103(3), 411-423.

Ashforth, B. E. \& Mael, F. (1989). Social identity theory and the organisation. Academy of Management Review, 14, 20-39.

Badea, M. (2014). Social media and organizational communication. Procedia - Social \& Behavioral Sciences, $149,70-75$.

Bagozzi, R. P. \& Yi, Y. (1988). On the Evaluation of Structural Equation Models. Journal of Academy of Marketing Science, 16(1), 74-94.

Baruah, T. D. (2012). Effectiveness of social media as a tool of communication and its potential for technologyenabled connections: a micro-level study. International Journal of Scientific \& Research Publications, 2(5), 1-10.

Becker, T. E. (1992). Foci and bases of commitment: Are they distinctions worth making? Academy of Management Journal, 35, 232-244.

Bian, W., Shang, J. \& Zhang, J. (2016). Two-way information sharing under supply chain competition. International Journal of Production Economics, 178, 82-94.

Bontis, N., Richards, D. \& Serenko, A. (2011). Investigating the role of information sharing, job characteristics, and employee satisfaction. The Learning Organization, 18(3), 239-250.

Brooks, S. \& Califf, C. (2016). Social media-induced technostress: its impact on the job performance of it professionals and the moderating role of job characteristics.

Burke, K. (1937). Attitudes Toward History. New York: The New Republic Publishing House.

Carmeli, A., Gilat, G. \& Waldman, D. A. (2007). The role of perceived organisational performance in organisational identification, adjustment and job performance. Journal of Management Studies, 44, 972-992.

Carmon, A. F., Miller, A. N., Raile, A. N. W. \& Roers, M. M. (2010). Fusing family and firm: Employee perceptions of perceived homophile, organisational justice, organisational identification, and organisational commitment in family businesses. Family Business Strategy, 1, 210-223.

Cheney, G. (1983). Organisational identification as process and product: a field study. Unpublished master's thesis. Indiana: Purdue University Press.

Chinomona, E. \& Omoruyi. O. (2017). Southern African Institute of Management Sciences (SAIMS) 2017 Conference proceedings. Free State. South Africa. www.saibw.co.za

Chumg, H. F., Seaton, J., Cooke, L. \& Ding, W. Y. (2016). Factors affecting employees' knowledge-sharing behavior in the virtual organisation from the perspectives of well-being and organizational behavior. Computers in Human Behaviour, 64, 432-448. 
Chung, A. Q. H., Andreev, P., Benyoucef, M., Duane, A. \& O’Reilly, P. (2016). Managing an organisation's social media presence: an empirical stage of growth model. International Journal of Information Management, 37, 1405-1417.

Dong, J. Q. \& Wu, W. (2015). Business value of social media technologies: Evidence from online user innovation communities. Journal of Strategic Information Systems, 24, 113-127.

Dukerich, J. M., Kramer, R. \& Parks, J. M. (1998). The dark side of organisational identification. In Whetton D.A. \& Godfrey P.C. eds. Identity in organisations: building theory through conversations. Thousand Oaks, CA: SAGE. pp. 245-256.

Ellemers, N., Spears, R. \& Doosje, B. (1997). Sticking together or falling apart: In-group identification as a psychological determinant of group commitment versus individual mobility. Journal of Personality and Social Psychology, 72, 617-626.

Felix, R., Rauschnabel, P. A. \& Hinsch, C. (2017). Elements of strategic social media marketing: a holistic framework. Journal of Business Research, 70, 118-126.

Gil-Garcia, R. \& Sayogo, D. S. (2016). Government inter-organisational information sharing initiatives: understanding the main determinants of success. Government Information Quarterly, 33, 572-582.

Gupta, P., Seetharaman, A. \& Raj, J. R. (2013). The usage and adoption of cloud computing by small and medium businesses. International Journal of Information Management, 33, 861-874.

Hansen, J. M. \& Levin, M. A. (2016). The effect of apathetic motivation on employees' intentions to use social media for businesses. Journal of Business Research, 69, 6058-6066.

Hatala, J. P. \& Lutta, J. G. (2009). Managing information sharing within an organizational setting: a social network perspective. Performance Improvement Quarterly, 21(4), 5-33.

Hogg, M. A. \& Vaughn, G. M. (2002). Social Psychology. 3rd edition. London: Prentice Hall.

Hogg, M. A., Abrams, D., Otten, S. \& Hinkle, S. (2004). The social identity perspective: Intergroup relations, self-conception, and small groups. Small Group Research, 35, 246-276.

Hussain, K., Konar, R. \& Ali, F. (2016). Measuring service innovation performance through team culture and knowledge sharing behavior in Hotel Services: a PLS approach. Procedia-Social \& Behavioral Sciences, 224, 35-43.

Ismaeel, N. \& Qammach, J. (2016). The mediating role of knowledge sharing on the relationship between IT capability and IT support as predictors of innovation performance: an empirical study on mobile companies in Iraq. Procedia Economics \& Finance, 39, 562-570.

Kuzu, O. H. \& Ozilhan, D. (2014). The effect of employee relationships and knowledge sharing on employees' performance: empirical research on the service industry. Procedia - Social \& Behavioral Science, 109, 1370-1374.

Kwahk, K. Y. \& Park, D. H. (2016). The effects of network sharing on knowledge-sharing activities and job performance in enterprise social media environments. Computers in Human Behavior, 55, 826-839.

Li, L., Qian, G. \& Qian, Z. (2012). The performance of small and medium-sized technology-based enterprises: Do product diversity and international diversity matter? International Business Review, 21, 941-956.

Li, X., Zhang, J., Zhang, S. \& Zhou, M. (2016). A multilevel analysis of the role of interactional justice in promoting knowledge-sharing behavior: the mediated role of organizational commitment. Industrial Marketing Management.

Llopis, O. \& Foss, N. J. (2016). Understanding the climate-knowledge sharing relation: the moderating roles of intrinsic motivation and job autonomy. European Management Journal, 34, 135-144.

Lotfi, Z., Mukhtar, M., Sahran, S. \& Zadeh, A. T. (2013). Information sharing in supply chain management. Procedia Technology, 11, 298-304.

Mael, F. \& Ashforth, B. E. (1992). Alumni and their alma mater: A partial test of the reformulated model of organisational identification. Journal of Organisational Behaviour, 13, 103-123.

Macnamara, J. \& Zerfass, A. (2012). Social media communication in organisations: the challenges of balancing openness, strategy and management. International Journal of Strategic Communication, 6(4), 287308.

Moghavvemi, S., Sharabati, M., Paramanathan, T. \& Rahin, N. M. (2017). The impact of perceived enjoyment, perceived reciprocal benefits and knowledge power on students' knowledge sharing through Facebook. The International Journal of Management Education, 15, 1-12.

Moshabbaki, A. \& Jaha'nyan, S. (2009). A trust-based model for knowledge sharing in ERP adopting organisations. Journal of Knowledge Management Practice, 10(1). 
Munirat, Y., Sanni, I. M. \& Kazeem, A. O. (2014). The impact of management information system (MIS) on the performance of business organization in Nigeria. International Journal of Humanities Social Sciences \& Education (IJHSSE), 1(2), 76-86.

Nascimento, A. M. \& da Silveira, D. S. (2016). A systematize mapping study on using social media for business process improvement. Computers in Human Behavior, 1-6.

Navimipour, N. J. \& Charband, Y. (2016). Knowledge sharing mechanisms and techniques in project teams: literature review, classification and current trends. Computers in Human Behaviour, 62, 730-742.

Nisaf, M. S. M. \& Wickramasinghe, V. (2013). Organizational policy as a moderator between online social networking and job performance. The Journal of Information and Knowledge Management Systems. 43(2), 161-184.

Nunnally, J. \& Bernstein, I. (1994). Psychometric theory. (3rd Edition). New York: McGraw-Hill.

Olaisen, J. \& Revang, 0. (2017). Working smarter and greener: collaborative knowledge sharing in virtual global project teams. International Journal of Information Management, 37, 1441-1448.

Ou, C. X. J., Davision, R. \& Wong, L. H. M. (2016). Using interactive systems for knowledge sharing: the impact of individual contextual preferences in China. Information \& Management, 53, 145-156.

Paulin, D. \& Suneson, K. (2012). Knowledge transfer, knowledge sharing and knowledge barriers - three blurred terms in KM. The Electronic Journal of Knowledge Management, 10(1), 81-91.

Pinho-costa, L., Yakubu, K., Hoedebecke, K., Laranjo, L., Reichel, C. P., Colon-Gonzalez, M. C., Neves, A. N. \& Errami, H. (2016). Healthcare hashtag index development: identifying global impact in social media. Journal of Biomedical informatics, 63, 390-399.

Pooe, D., Mafini, C. \& Loury-Okoumba, V. W. (2015). The influence of information sharing, supplier trust and supplier synergy on supplier performance: the case of small and medium enterprises. Journal of Transport \& Supply Chain Management, 9(1), 1-11.

Pratt, M. G. (1998). To be or not to be? Central questions in organisational identification. In Whetton, D. A. \& Godfrey, P. C., eds. Identity in Organizations: Building Theory Through Conversations. Thousand Oaks, CA: SAGE. pp. 171-207.

Quinton, S. \& Wilson, D. (2016). Tensions and ties and social media networks: towards a model of understanding business relationship development and business performance enhancement through the use of LinkedIn. Industrial Marketing Management, 54, 15-24.

Rauniar, R., Rawski, G., Yang, J. \& Johnson, B. (2014). Technology acceptance model (TAM) and social media usage: an empirical study on Facebook. Journal of Enterprise Information Management, 27(1), 6-30.

Razak, N. A., Pangil, F., Md Zin, M. L., Azlina, N., Yunus, M. \& Asnawi, N. H. (2016). Theories of knowledge sharing behavior in business strategy. Procedia Economics and Finance, 37, 545-553.

Razak, N. A., Pangil, F., Zin, M. L. M., Yunus, N. M. Y. \& Asnawi, N. H. (2016). Theories of knowledge sharing behavior in business strategy. Procedia Economics and Finance, 37, 545-553.

Ryden, P., Ringberg, T. \& Wilke, R. (2015). How managers' shared mental models of business-customer interactions create different sense-making of social media. Journal of Interactive Marketing, 31, 1-16

Saboo, A. R., Kumar, V. \& Ramani. (2016). Evaluating the impact of social media activities on human brand sales. International Journal of Research in Marketing, 33, 524-541.

Saboo, A. R., Kumar, V. \& Ramani, G. (2016). Evaluating the impact of social media activities on human brands sales. International Journal of Research in Marketing, 33, 524-541.

Scott, C. R. (2007). Communication and Social Identity Theory: Existing and potential connections in organisational identification research. Communication Studies, 58, 123-138.

Sidorova, Y., Amaboldi, M. \& Radaelli, J. (2016). Social media and performance measurement systems: towards a new model. International Journal of Productivity and Performance Management, 65(2), 139-161.

Sivertzen, A. M., Nilsen, E. R. \& Olafsen, A. H. (2013). Employer branding: employer attractiveness and the use of social media. Journal of Product \& Brand Management, 22(7), 473-483.

Srikanth, P. B. \& Jomon, M. G. (2013). Role ambiguity and role performance effectiveness: moderating the effect of feedback-seeking behavior. Asian Academy of Management Journal, 18(2), 105-127.

Swani, K., Milne, G. R., Brown, B. P., Assaf, A. G. \& Donthu, N. (2016). What messages to post? Evaluating the

popularity of social media communications in business versus consumer markets. Industrial Marketing Management.

Tajfel, H. \& Turner, J. (1979). An integrative theory of intergroup conflict. In Austin W.G. \& Worschel, S., eds. The social psychology of intergroup relations. Monterey, CA: Brooks/Cole. pp. 33-47. 
Terry, D., Hogg, M. \& White, K. (1999). The theory of planned behaviour: Self-identity, social identity, and group norms. British Journal of Social Psychology, 38, 225-244.

Tong, P. Y. \& Crosno, J. (2016). Are information asymmetry and sharing good, bad, or context dependent? A meta-analytic review. Industrial Marketing Management, 56, 167-180.

Trivellas, P., Akrivouli, Z., Tsifora, E. \& Tsoutsa, P. (2015). The impact of knowledge sharing culture on job satisfaction in accounting firms. The mediating effect of general competencies. Procedia Economics \& Finance, 19, 238-247.

Tseng, S. M. \& Huang, J. S. (2011). The correlation between Wikipedia and knowledge sharing on job performance. Expert System with Applications, 38, 6118-6124.

Van Dick, R., Christ, O., Stellmacher, J., Wagner, U., Ahlswede, O. \& Grubba, C. (2004). Should I stay or should I go? Explaining turnover intentions with organisational identification and job satisfaction. British Journal of Management, 15, 351-360.

Vasquez, L. M. G. \& Velez, I. S. (2011). Social media as a strategic tool for corporate communication. Revista Internacional De Relaciones Publicas, 2(1), 157-174.

Wang, W. Y. C., Pauleen, D. J. \& Zhang, T. (2016). How social media applications affect B2B communication and improve business performance in SMEs. Industrial Marketing Management, 54, 4-14.

Wang, Z., Sharma, P. N. \& Cao, J. (2016). From knowledge sharing to firm performance: a predictive model comparison. Journal of Business Research, 69, 4650-4658.

Wu, C. W. (2016). The performance impact of social media in the chain store industry. Journal of Business Research, 69, 5310-5316.

Wu, I. L., Chuang, C. H. \& Hsu, C. H. (2014). Information sharing and collaborative behaviors in enabling supply chain performance: a social exchange perspective. International Journal of Production Economics, 148, 122-132.

Wu, Y. L., Li, E. Y. \& Chang, W. L. (2016). Nurturing user creative performance in social media networks: an integration of habit of use with social capital and information exchange theories. Internet Research, 26(4), 869-900.

Zellweger, T. M., Eddleston, K. A. \& Kellermanns, F. W. (2010). Exploring the concept of familiness: introducing family firm identity. Journal of Family Business Strategy, 1, 54-63. 